\title{
Westinghouse Hanford Company Pollution Prevention Program Implementation Plan
}

\author{
B. C. Floyd
}

Date Published

October 1994

Prepared for the U.S. Department of Energy Office of Environmental Restoration and Waste Management

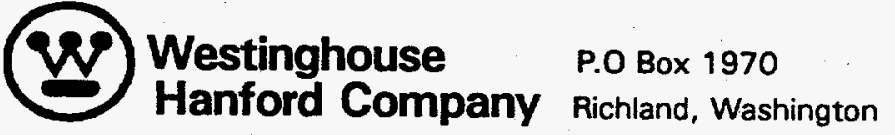

Hanford Operations and Engineering Contractor for the

U.S. Depertment of Energy under Contract DE-ACO6-87RL10930 


\section{RELEASE AUTHORIZATION}

Document Number: WHC-EP-0496, Rev. 1

Document Title: Westinghouse Hanford Company Waste Minimization and Pollution Prevention Awareness Program Plan

Release Date: $\quad 11 / 1 / 94$

This document was reviewed following the procedures described in WHC-CM-3-4 and is:

APPROVED FOR PUBLIC RELEASE

WHC Information Release Administration Specialist:

C.gillingthesol

C. Willingham 


\section{DISCLAIMER}

This report was prepared as an account of work sponsored by an agency of the United States Government. Neither the United States Government nor any agency thereof, nor any of their employees, make any warranty, express or implied, or assumes any legal liability or responsibility for the accuracy, completeness, or usefulness of any information, apparatus, product, or process disclosed, or represents that its use would not infringe privately owned rights. Reference herein to any specific commercial product, process, or service by trade name, trademark, manufacturer, or otherwise does not necessarily constitute or imply its endorsement, recommendation, or favoring by the United States Government or any agency thereof. The views and opinions of authors expressed herein do not necessarily state or reflect those of the United States Government or any agency thereof. 


\section{DISCLAIMER}

Portions of this document may be illegible in electronic image products. Images are produced from the best available original document. 


\section{CONTENTS}

GLOSSARY . . . . . . . . . . . . . . . . . . . . . v

1.0 .INTRODUCTION/BACKGROUND . . . . . . . . . . . . . . . . . . . 1-1

1.1 PURPOSE OF IMPLEMENTATION PLAN . . . . . . . . . . . . . 1-1

1.2 SCOPE . . . . . . . . . . . . . . . . 1-1

1.3 LEGAL AND POLICY BACKGROUND ................ . . . 1-3

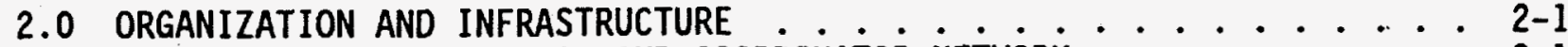

2.1 PROGRAM INTEGRATION AND COORDINATOR NETWORK $2-1$

2.2 U.S. DEPARTMENT OF ENERGY PROGRAM PARTICIPATION . . . . . . . . 2-1

2.3 PROGRAM ORGANIZATION AND RESPONSIBILITIES ..........

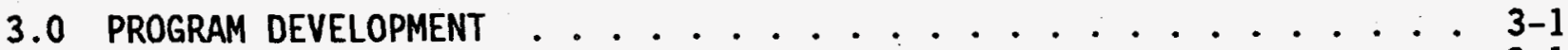

3.1 POLICY . . . . . . . . . . . . . . . . 3-1

3.2 PLANNING ...................... . . . . . . . .

3.3 STRATEGY . . . . . . . . . . . . . . . . . $3-2$

3.4 PROGRAM OBJECTIVES ................. . . . . . . . .

3.5 GOALS . . . . . . . . . . . . . . . . 3-5

3.6 IMPLEMENTATION SCHEDULES ................... 3-5

3.7 FUNDING ...................... . . . . . . . .

3.8 PERSONNEL . . . . . . . . . . . . . . . . 3-6

3.9 OPERATING PROCEDURES ........................ 3-6

3.10 QUALITY ASSURANCE ................. . . . . . . . . . . .

4.0 EMPLOYEE INVOLVEMENT . . . . . . . . . . . . . . . . . . . . . 4-1

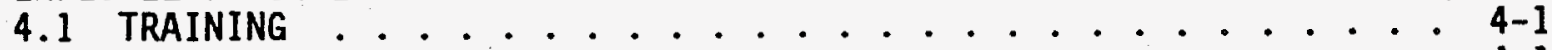

4.2 AWARENESS ........................ . . . . . .

4.3 INCENTIVES . . . . . . . . . . . . . . . . . . . 4-2

5.0 TRACKING . . . . . . . . . . . . . . . . . . . . . 5-1

5.1 EMERGENCY PREPAREDNESS AND COMMUNITY RIGHT-TO-KNOW ACT
MATERIAL INVENTORY TRACKING . . . . . . . . . . 5-1

5.2 WASTE TRACKING . . . . . . . . . . . . . . . . 5-2

5.3 OPPORTUNITY ASSESSMENT TRACKING ... . . . . . . . . . . 5-2

5.4 COST TRACKING AND ACCOUNTING . . . . . . . . . . . . 5-3

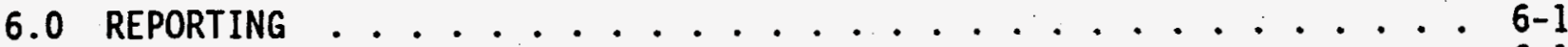

6.1 COMPLIANCE REPORTING ................. . . . . . . . .

6.2 REPORTS TO THE U.S. DEPARTMENT OF ENERGY . . . . . . . . . . . 6-1

7.0 SITEWIDE WASTE REDUCTION ... . . . . . . . . . . . . . . . . 7-1

7.1 TOXICS REDUCTION/MATERIAL SUBSTITUTION . . . . . . . . . . $7-1$

7.2 MATERIAL EXCHANGE ...................... . . . . . .

7.3 RECYCLING/REUSE . . . . . . ............. . . 7-1

7.4 AFFIRMATIVE PROCUREMENT . . . . . . . . . . . . . . . . 7-2

8.0 TECHNICAL ASSISTANCE . . . . . . . . . . . . . . . . 8-1

8.1 GOAL SETTING .................... . 8-1

8.2 BASELINE DETERMINATION . . . . . . . . . . . . . . . 8-1

8.3 OPPORTUNITY ASSESSMENTS . . . . . . . . . . . . . . . 8-1

8.4 MODEL PROGRAMS .................... . . . . . . 
WHC-EP-0496, Rev. 1

8.5 PROGRAM ACTIVITY TRACKING . . . . . . . . . . . 8-2

9.0 INFORMATION AND TECHNOLOGY EXCHANGE ............... $9-1$

9.1 SEMINARS, WORKSHOPS, AND MEETINGS ................ 9-1

9.2 INFORMATION CLEARINGHOUSE .................. . 9-1

9.3 OUTREACH AND PUBLIC RELATIONS . . . . . . . . . . . . . . 9-1

10.0 RESEARCH AND DEVELOPMENT . . . . . . . . . . . . . . . 10-1

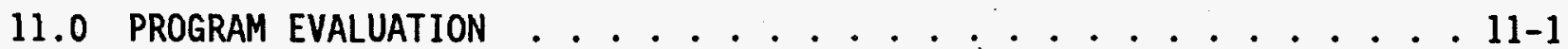

11.1 EMPLOYEE PARTICIPATION . . . . . . . . . . . . . . . . . 11-1

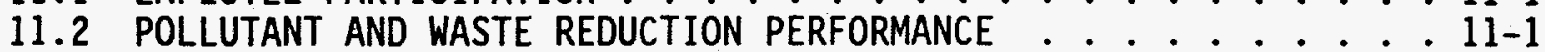

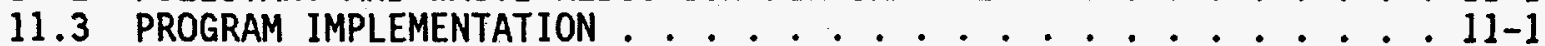

12.0 REFERENCES . . . . . . . . . . . . . . . . . . 12-1 APPENDICES

A U.S. ENVIRONMENTAL PROTECTION AGENCY WASTE MINIMIZATION

PROGRAM ELEMENTS GUIDANCE COMPLIANCE MATRIX . . . . . . . . . . A-1

B GENERATOR GROUP P2 PROGRAM DOCUMENTATION . . . . . . . . . . . B-1

C WESTINGHOUSE HANFORD COMPANY POLLUTION PREVENTION AND WASTE

MINIMIZATION POLICY . . . . . . . . . . . . . . . . . . C-1

D HANFORD SITE WMIN/P2 PROGRAM REQUIREMENTS

IMPLEMENTATION SCHEDULE ..................... D-1

E WESTINGHOUSE HANFORD COMPANY POLLUTION PREVENTION

PROGRAM FUNDING

FIGURES

1 POLLUTION PREVENTION PROGRAM SCOPE ................. . . . . .

2 POLLUTION PREVENTION PROGRAM HIERARCHY . . . . . . . . . . . . . 1-4 
WHC-EP-0496, Rev. 1

\section{GLOSSARY}

\section{DEFINITIONS OF TERMS}

Generator - Each contractor within the scope of the Westinghouse Hanford Company P2 Program whose activities or processes produce waste (Westinghouse Hanford Company; BCS Richland, Inc.; and ICF Kaiser Hanford Company).

Generator Group - As defined by the responsible contractor (Westinghouse Hanford Company; BCS Richland, Inc.; or ICF Kaiser Hanford Company), any discrete activity, project, or facility whose act or process produces waste.

Hazardous substance - Any hazardous substance listed as a hazardous substance in the Emergency Planning and Community Right-to-Know Act and any further updates, and all ozone depleting compounds as defined by the Montreal Protocol of October 1987 and any further updates of the protocol.

Hazardous waste - Those solid wastes that exhibit any of the characteristics of hazardous waste identified in 40 CFR 261, Subpart C (e.g., ignitable, corrosive, reactive, acutely hazardous or acutely toxic), or that are 1 isted in 40 CFR 261, Subpart D, "List of Hazardous Waste." Also includes dangerous waste as defined in WAC 173-303.

Pollution prevention - The use of materials, processes, or practices that reduce or eliminate the creation of pollutants or wastes at the source. It includes practices that reduce the use of hazardous and nonhazardous materials, energy, water, or other resources as well as those that protect natural resources through conservation or more efficient use.

Recycling - Recycling techniques are characterized as use, reuse, and reclamation techniques (resource recovery). Use or reuse involves the return of a potential waste material either to the originating process as a substitute for an input material or to another process as an input material. Reclamation is the recovery of a useful or valuable material from a waste stream. Recycling allows potential waste materials to be put to a beneficial use instead of going to treatment, storage, or disposal.

Source reduction - The elimination or reduction of waste generation at the source. Source reduction activities and techniques include substitution of less hazardous materials, process optimization or modification, technology changes and administrative changes (inventory control), and housekeeping practices (waste segregation). Source reduction results in reducing or eliminating potential waste material exiting from a process. 
WHC-EP-0496, Rev. 1

Treatment - Technological processes that reduce the quantity, toxicity, or mobility of waste. Examples include, but are not limited to, incineration, vitrification, neutralization, chemical extraction, physical separation, and solidification/stabilization technologies.

Waste minimization - Elimination or minimization of the generation of waste before treatment, storage, or disposal. Waste minimization is any source reduction or recycling activity that results in (1) reduction of total quantity of waste, (2) reduction of toxicity of waste, or (3) both, as long as that reduction is consistent with the general goal of minimizing present and future threats to human health and the environment.

Waste reduction. Reduction of the total amount of waste that is generated and disposed of by U.S. Department of Energy operations through waste minimization and treatment activities.

\section{ACRONYMS}

$\begin{array}{ll}\text { ADS } & \text { Activity Data Sheets } \\ \text { BCSR } & \text { BCS Richland, Inc. } \\ \text { DOE } & \text { U.S. Department of Energy } \\ \text { ECOlogy } & \text { Washington State Department of Ecology } \\ \text { EO } & \text { Executive Order } \\ \text { EM } & \text { Environmental Management } \\ \text { EPA } & \text { U.S. Environmental Protection Agency } \\ \text { FY } & \text { Fiscal Year } \\ \text { GOCO } & \text { Government-Owned, Contractor-Operated } \\ \text { HMID2 } & \text { Hazardous Material Inventory Database 2 } \\ \text { HQ } & \text { Headquarters } \\ \text { ICF KH } & \text { ICF Kaiser Hanford Company } \\ \text { P2 } & \text { Westinghouse Hanford Company Pollution Prevention } \\ \text { P20A } & \text { (formerly Waste Minimization) (Program) } \\ \text { RL } & \text { Pollution Prevention Opportunity Assessment } \\ \text { SWITS } & \text { (formerly Process Waste Assessment) } \\ \text { WHC } & \text { U.S. Department of Energy, Richland Operations (Office) } \\ \text { WMin/P2 } & \text { Solid Waste Information and Tracking System } \\ & \text { Westinghouse Hanford Company } \\ & \text { Hanford Site Waste Minimization and Pollution Prevention }\end{array}$


WHC-EP-0496, Rev. 1

WESTINGHOUSE HANFORD COMPANY POLLUTION PREVENTION PROGRAM IMPLEMENTATION PLAN

\subsection{INTRODUCTION/BACKGROUND}

\subsection{PURPOSE OF IMPLEMENTATION PLAN}

This plan documents Westinghouse Hanford Company's (WHC) Pollution Prevention (P2) (formerly Waste Minimization) program. The program includes WHC; BCS Richland, Inc. (BCSR); and ICF Kaiser Hanford Company (ICF KH). The plan specifies P2 program activities and schedules for implementing the Hanford Site Waste Minimization and Pollution Prevention Awareness (WMin/P2) Program Plan requirements (DOE 1994a). It is intended to satisfy the U.S. Department of Energy (DOE) and other legal requirements that are discussed in both the Hanford Site WMin/P2 plan and paragraph C of this plan. As such, the Pollution Prevention Awareness Program required by DOE Order 5400.1 (DOE 1988) is included in the WHC P2 program.

WHC, BCSR, and ICF KH are committed to implementing an effective P2 program as identified in the Hanford Site WMin/P2 P1an. This plan provides specific information on how the WHC P2 program will develop and implement the goals, activities, and budget needed to accomplish this. The emphasis has been to provide detailed planning of the WHC P2 program activities over the next 3 years. The plan will guide the development and implementation of the program. The plan also provides background information on past program activities. Because the plan contains greater detail than in the past, activity scope and implementation schedules may change as new priorities are identified and new approaches are developed and realized. Some activities will be accelerated, others may be delayed; however, all of the general program elements identified in this $\mathrm{plan}$ and contractor requirements identified in the Site WMin/P2 plan will be developed and implemented during the next 3 years.

This plan applies to all WHC, BCSR, and ICF KH organizations and subcontractors. It will be distributed to those with defined responsibilities in this plan; and the policy, goals, objectives, and strategy of the program will be communicated to all WHC, BCSR, and ICF KH employees. The plan aiso can be used as a reference tool, along with the Hanford Site WMin/P2 plan, for managers, operations personnel, and support staff to incorporate pollution prevention into all applicable activities. This plan will be reviewed annually and revised as necessary. At a minimum, the implementation plan will be updated every 3 years.

\subsection{SCOPE}

The scope of the WHC P2 program includes source reduction, recycling, treatment, and resource and energy conservation (Figure 1). P2 is used as an all encompassing term to capture the range and hierarchy of environmental management activities that make up the WHC P2 program. The program is an organized, comprehensive, and continual effort to systematically reduce hazardous, radioactive, mixed, and sanitary wastes; conserve resources; and prevent or minimize pollutant releases to all environmental media from all WHC, BCSR, and ICF KH activities and operations. 
WHC-EP-0496, Rev. 1

Figure 1. Pollution Prevention Program Scope.

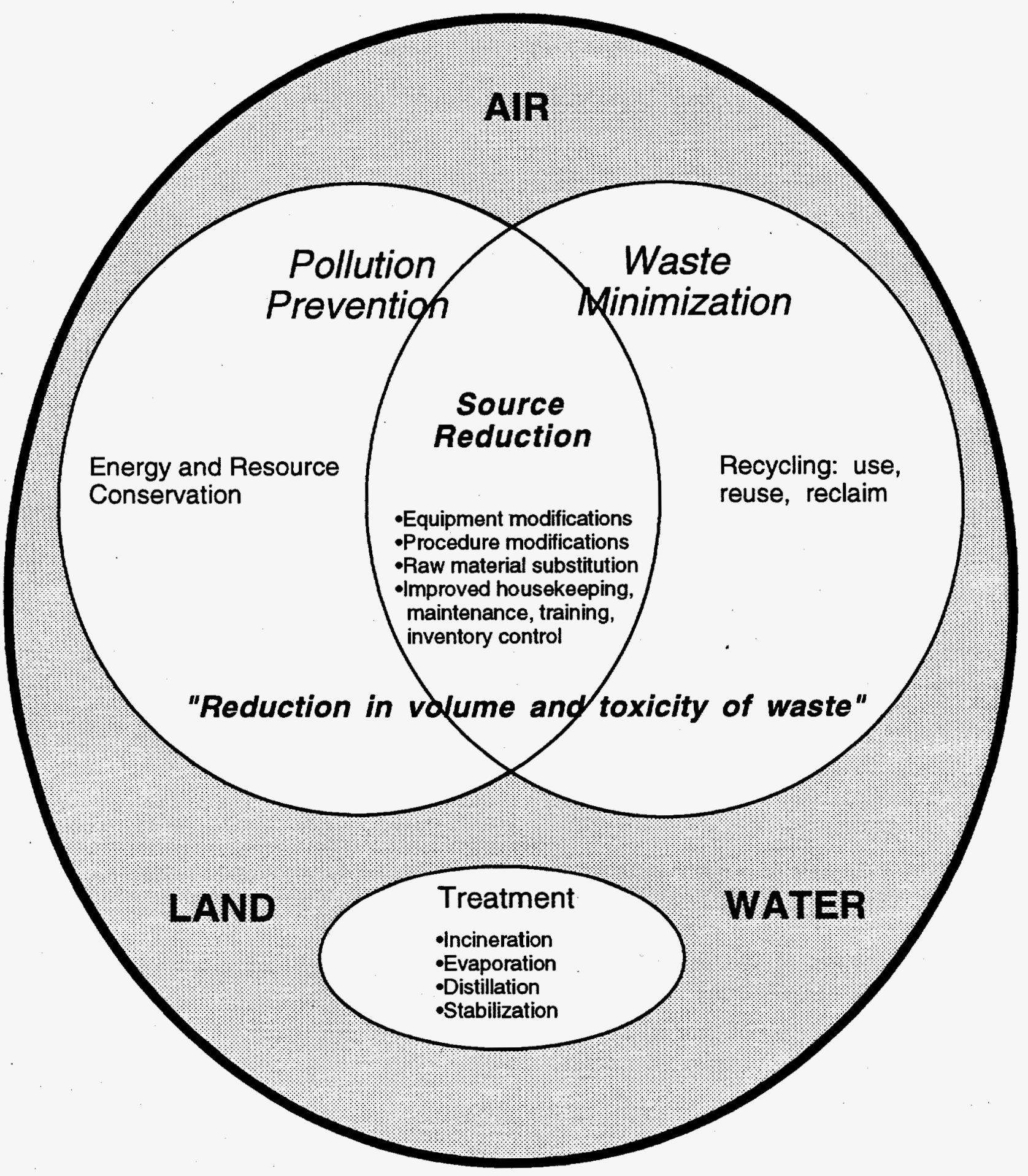


The plan contains details on the implementation of national, state, DOE, and generator P2 goals and policies, and represents an ongoing effort to make P2 part of WHC, BCSR, and ICF KH operating philosophies.

In accordance with these policies, a hierarchical approach to environmental management has been adopted (Figure 2) and is applied to all types of polluting and waste generating activities. Pollution prevention and waste minimization through source reduction are first priority in the WHC P2 program, followed by environmentally safe recycling. Treatment to reduce the quantity, toxicity, and/or mobility will be considered only when prevention or recycling are not possible or practical. Environmentally safe disposal is the last option.

\subsection{LEGAL AND POLICY BACKGROUND}

The regulatory and policy requirements for pollution prevention and waste minimization include, but are not limited to, the law and policies listed below and the laws, regulations, Executive Orders, DOE Orders, and policies identified in the Site WMin/P2 plan.

Additionally, the WHC P2 program is established in accordance with the U.S. Environmental Protection Agency (EPA) guidance for key elements of a waste minimization program. A matrix in Appendix $A$ identifies whether the implementation of program elements are described in the Site WMin/P2 P1an, the WHC Implementation Plan, or generator group program documentation.

Chapter 173-307 Washington

Administrative Code, Hazardous Waste

Facilities PI ans [DOE-Rich Tand

Operations ( $R L$ ) directed contractors to voluntarily comply] (DOE-RL 1992)

RL Policy "Pollution Prevention Policy for Richland Operations" (1994b)

RL "Guidance on the Management of Office Waste" (1994c)

WHC Policy, "Pollution Prevention and Waste Minimization"

WHC Policy, "Waste Generating Pol icy"
Sets voluntary goals for hazardous waste reduction and guidelines for generator group programs. Requests annual progress reporting.

Commitment to: an effective waste minimization and pollution prevention program at Hanford, the DOE 1994 WMin/P2 Crosscut Plan, and recent Executive Orders.

Provides guidance to the Site on the management and minimization of office waste.

Commitment to an effective pollution prevention program at Hanford.

Waste minimization to be considered in preplanning prior to the generation of waste. 
WHC-EP-0496, Rev. 1

Figure 2. Pollution Prevention Program Hierarchy.

\section{Source Reduction}

\section{Recycling}

\section{Waste Treatment}

\section{Disposal}


WHC-EP-0496, Rev. 1

\subsection{ORGANIZATION AND INFRASTRUCTURE}

\subsection{PROGRAM INTEGRATION AND COORDINATOR NETWORK}

The WHC P2 program organization and infrastructure is designed to integrate and coordinate program activities among WHC, BCSR, and ICF KH. Current program organization is different from past practice, where contractors operated independent programs.

The full program network and responsibilities for organizations new to the program will be established during fiscal year (FY) 1995 . Full program establishment means identifying all generator group $P 2$ representatives, assigning WHC Pollution Prevention and ICF KH staff to support individual generator group programs, holding quarterly meetings with Site representatives, and having consistent generator group programs throughout the three companies.

Program coordination will occur through meetings held at least quarterly. All program-related personnel and other interested parties will be invited to attend these meetings, which will provide the forum for sharing and exchanging important program information, including P2 technologies and initiatives.

\subsection{U.S. DEPARTMENT OF ENERGY PROGRAM PARTICIPATION}

WHC, BCSR, and ICF KH will participate in the DOE complex-wide P2 program. The WHC Pollution Prevention organization will coordinate WHC, BCSR, and ICF KH participation through developing and issuing program guidance in accordance with DOE requirements and program objectives, and through communicating DOE requirements to all applicable organizations.

\subsection{PROGRAN ORGANIZATION AND RESPONSIBILITIES}

The WHC P2 program is directly supported and implemented by the following organizations and programs: WHC Pollution Prevention, WHC Recycling, WHC Procurement, BCSR Network Performance Management, ICF KH Environmental Programs and Integration, ICF KH Energy Management; and WHC, BCSR, and ICF KH generator group P2 programs. The following is a breakdown of major responsibilities for the organizations and programs currently supporting the program. Responsibilities correlate with the regulatory and DOE requirements identified in the Hanford Site WMin/P2 Plan.

\subsubsection{WHC Pollution Prevention}

Pollution Prevention organizes the WHC P2 program and has been assigned the role of lead coordinator among site contractors to support RL in the development and implementation of the sitewide program. The RL Pollution Prevention program manager will coordinate site program activities through WHC Pollution Prevention, some of whose specific responsibilities are identified below:

- Developing sitewide program elements that encourage and facilitate P2 
- Providing pollution prevention opportunity assessment (P20A) training, and develops incentive and awareness programs

- Developing tracking and reporting systems

- Collecting information for reporting summary pollution prevention and waste minimization efforts to DOE and regulatory agencies

- Assisting in the establishment of generator group representatives and teams

- Assisting generator groups in establishing goals in accordance with Executive Order (EO) 12856, Federal Agency Compliance with Right-to-Know Laws and Pollution Prevention Requirements, issued 1993, and DOE goal setting guidance (DOE 1994a).

- Assisting in obtaining management support and budget for P2 activities

- Assisting generator groups in development and implementation of their P2 programs

- Leading the development and implementation of sitewide initiatives except for material exchange, recycling, and affirmative procurement

- Championing technical initiatives

- Coordinating P2 requirements for all Hanford Site contractors

- Responding to DOE-Headquarters (HQ) requests

- Interpreting legislative and DOE P2 program requirements

- Evaluating award fee against pollution prevention award fee criteria for WHC, BCSR, and ICF KH.

\subsubsection{WHC Recycling}

A few specific responsibilities of WHC Recycling follow:

- Developing, implementing, and maintaining programs to recycle, reuse, and excess materials, commodities, and recoverable scrap with onsite and offsite end users

- Assisting and advising procurement organizations in the purchasing of recycled and recyclable products.

\subsubsection{WHC Procurement}

WHC Procurement responsibilities include:

- Implementing practices, where economically practicable, that minimize the procurement of class I ozone-depleting substances. 
Complies with EO 12843, Procurement Requirements and Policies for Ozone-Depleting Substances, issued Apri1, 1993.

- Providing support to activities that reduce procurement of hazardous materials as defined by the Resource Conservation and Recovery Act of 1976, WAC 173-303, and EO 12873, Federal Acquisition, Recycling and Waste Prevention, issued October, 1993.

- Implementing an affirmative procurement program for products that have a post-consumer recycled content.

\subsubsection{BCSR Network Performance Management} requirements.

Network Performance Management coordinates the BCSR P2 program

\subsubsection{ICF KH Environmental Programs and Integration}

Environmental Programs and Integration develops and implements the policy, plans, procedures, and systems that constitute the overall ICF KH P2 program. Specific responsibilities of the organization include the following:

- Developing and implementing the ICF KH P2 program and the associated affirmative procurement and ozone depleting substance reduction program

- Collecting and consolidating ICF KH P2 information and data for reporting and tracking purposes

- Assisting ICF KH generator groups in championing P2 and waste minimization activities

- Ensuring P2 activities and approaches satisfy regulatory and other requirements

- Providing a single point-of-contact to coordinate P2 activities within ICF KH and external organizations

- Consulting with WHC P2 organizations to Teverage available expertise and resources.

\subsubsection{ICF KH Energy Management}

Energy Management has the charter to insure continued operation of Hanford facilities and programs with the lowest possible energy consumption and no interruption of essential programmatic missions. This includes complying with energy conservation requirements in EO 12902, Energy Efficiency and Water Conservation at Federal Facilities, issued March 1994. They also are responsible for improving efficiency and productivity of plant facilities. Specifically, Energy Management:

- Develops and implements new energy conservation measures and initiatives at the Hanford Site to ensure cost effective operations 
- Tracks and analyzes energy usage data to identify new energy savings opportunities

- Cultivates employee and community energy awareness.

\subsubsection{WHC, BCSR, and ICF KH Waste Generator Group P2 Programs}

Generator groups develop P2 programs in accordance with the recently issued Executive Orders and other regulatory requirements identified in this plan and the Site plan. Programs will be organized according to the key program elements identified in the DOE WMin/P2 Crosscut P1an (1994b). Some specific generator group responsibilities follow:

- Establishing and track against goals

- Establishing resource requirements and activity schedules

- Prioritizing pollutants and waste streams

- Establishing P2OA teams

- Performing P20As on priority waste streams and identify costeffective P2 opportunities

- Implementing cost-effective P2 opportunities

- Identifying research and development needs

- Incorporating P2 into the design of new projects or activities

- Evaluating program implementation and performance

- Participating in the sitewide program

- Implementing corrective actions

- Documenting programs through maintaining the program documentation identified in Appendix B

- Reporting quarterly and annually on program progress and accompli shments. 


\subsection{PROGRAM DEVELOPMENT}

The DOE-HQ Office of Environmental Management (EM) Waste Minimization Division (EM-334) has provided funding to the WHC P2 program for development of program elements and tools to be used within the WHC, Site and DOE complex P2 programs. Some of the tools recently developed are design guidelines and training for the DOE complex on incorporating P2 in the design of new or modified facilities, a WHC P2 program baseline, and establishing a Hanford goal setting methodology. These tools, and others described in this plan, will be used to implement the program policy and objectives described below. Key to this implementation will be to ensure adequate resources and trained personnel exist to support the achievement of program goals and objectives. Full program implementation of the following key sitewide and generator group program elements will begin October 1, 1994 .

\subsection{POLICY}

The WHC "Pollution Prevention and Waste Minimization" Policy, issued May 26, 1994 (Appendix C), states:

We will conduct our operations and activities in a way that minimizes the quantity and toxicity of wastes generated, eliminates or minimizes pollutant releases to the environment, and minimizes the use of toxic substances. This will be done through better design, product acquisition, and changes in technologies, work practices, and procedures.

WHC, BCSR, and ICF KH are committed to establishing and maintaining an effective $\mathrm{P} 2$ program that implements the requirements of the Site WMin/P2 plan. Adequate personnel, budget, training, and material will be provided to accomplish this objective.

\subsection{PLANNING}

Program planning is performed for the generator and generator group programs. Past program activity planning was conducted through preparing a sitewide plan, contractor plans, and facility plans. Each of these plans contained general program information and requirements. The facility plans also contained facility-specific information. The new planning approach is to have the Site plan contain all the general program requirements. The WHC P2 Program plan does not repeat general information contained in the Site plan. Instead it identifies activities, schedules, and budgets to implement the program requirements stated in the Site plan.

The WHC P2 Program Implementation plan also contains information not identified in the Site plan for generator groups to reference for documentation of their individual programs. Generator groups will no longer be required to prepare individual plans. Instead they will have program documentation on file to demonstrate their P2 program meets Site requirements. Their program documentation will consist of goals; budget, activities, and schedule information; P20A; and pollution prevention reporting information (Appendix B). The purpose of this change in documenting generator group P2 programs is to eliminate unnecessary preparation of general program 
WHC-EP-0496, Rev. 1

information common to all generator groups. It concentrates generator group efforts on the more effective $P 2$ program planning and implementation activities. WHC Pollution Prevention and ICF KH Environmental Programs and Integration will support generator groups in their preparation of program documentation and in their implementation efforts. Goals and budget information will be developed annually. P20A and opportunity implementation will be ongoing. Reports will be prepared quarterly and annually. The Guide for Preparing and Maintaining Generator Group Pollution Prevention Program Documentation provides specific information on the requirements for these activities and how to document them (WHC 1994a).

\subsection{STRATEGY}

The WHC P2 program strategy is to develop and implement a P2 program at Hanford that achieves program objectives through effective and efficient P2 methodologies tailored to generator activities and operations. This will include establishing goals and identifying priority activities and resource requirements. Emphasis will be placed on integrating these goals, activities, and budgets to prevent pollution and reduce waste.

An essential part of the strategy is to continually obtain accurate, current, and specific hazardous substance and energy use, pollutant release, and waste generation information on current activities. The Hazardous Material Inventory Database 2 (HMID2) and the Solid Waste Information and Tracking System (SWITS) will have an important role in establishing these baselines. Details on how these databases will support the program are provided in Section 5.0 of this plan. These databases will provide much of the necessary baseline information needed to identify priority areas for concentrating program resources. Those pollution prevention activities that will help achieve program goals and result in the highest safety, health, and environmental benefits, and the highest economic returns on investment will be top priority for program personnel and resources.

The strategy is implemented through sitewide P2 initiatives and through individual generator group P2 activities.

\subsubsection{Sitewide Initiatives}

Coordinating and championing sitewide initiatives is an essential element of implementing an efficient and cost-effective P2 program. Existing sitewide initiatives include recycling programs for excess chemicals, paper and cardboard, wood, and scrap metal; the Hazardous Materials Reduction Initiative, which is a centralized system and database for controlling the procurement of hazardous chemicals; and incorporating P2 into project planning and facility design.

These initiatives will be fully implemented at the Site. In the future, the recycling program will be expanding wood and cardboard recycling efforts. The Hazardous Materials Reduction Initiative is available for WHC, BCSR, and ICF KH generator groups and soon will be made available to other Site contractors. Incorporating P2 into project planning and design will be accomplished through revising Site design guidelines and requirements. An automated electronic guideline for Site designers is also being developed for use onsite and will be available in Fy 1995. 


\subsubsection{Generator Groups}

A primary element of the P2 strategy is to modify generator activities to reduce pollutant releases and waste generation. Hanford's new mission of environmental restoration has changed the nature of most activities performed onsite from routine to discontinuous or project-oriented activities. The strategy is to divide these different activities into pollutant/waste generator groups based on the nature of work being performed. Generator groups will be organized consistent with established Site programs and funding structures. Each generator group will have direct access to a Environmental Compliance Officer or environmental coordinator who can support the group in complying with P2 regulatory requirements, and can work with generator group P2 personnel and their management to ensure sufficient resources are dedicated to $\mathrm{P2}$ activities to meet a11 regulatory requirements.

Generator group activities, like facility activities in the past, will be assessed for P2 opportunities. This involves developing lists of priority pollutants and waste streams, performing P20As on priority activities, and identifying and implementing opportunities. Tools, such as a Hanford P2OA process, are being developed with the flexibility needed to adapt to the various types of activities being performed by each generator.

\subsection{PROGRAM OBJECTIVES}

The objectives of the WHC P2 Program are described below. These objectives were developed from regulatory and DOE requirements, and from input provided by WHC P2 Program contractors and generator group P2 representatives. The key objectives identify the high-level results that will be achieved and the strategic objective identify specific activities that will be accomplished to achieve the key objectives.

\subsubsection{Key Objectives}

- Prevent pollution, minimize waste, and conserve energy and resources.

- Achieve measurable results and streamline the process for implementing $\mathrm{P} 2$ requirements.

- Comply with Federal, state, and DOE requirements for pollution prevention, waste minimization, waste reduction, and resource and energy conservation.

The strategic objectives, which support the key program objectives listed above, are divided into four categories: infrastructure, development, implementation, and communication. 
WHC-EP-0496, Rev. 1

\subsubsection{Strategic Objectives}

\section{A. Infrastructure}

- Obtain the necessary funding and management support to fully implement a successful P2 program.

- Target and change policies, procedures, or practices that are barriers to $\mathrm{P} 2$.

- Incorporate P2 into the WHC, BCSR, and ICF KH work planning and procedures system.

B. Development

- Establish pollutant release and waste generation baselines and projections for WHC, BCSR, and ICF KH, broken down by individual generator groups.

- Establish quantifiable P2 goals, and identified priority activities and schedules for achieving measurable $P 2$ results.

- Develop and implement user-friendly P2 tools and methodologies.

- Contribute to the development of the DOE WMin/P2 complex-wide program.

C. Implementation

- Champion P2 initiatives at Hanford, within the DOE complex, and in the community.

- Prepare and issue all required reports in a professional and timely manner.

- Perform pollution prevention opportunity assessments on priority pollutant release and waste generating activities.

- Identify and implement cost-effective P2 opportunities.

- Promote a positive behavior change toward P2 through training, awareness, and incentives.

- Communicate P2 goals, objectives, and implementation strategies to employees and to all levels of management.

- Share P2 techniques and accomplishments through onsite networking, technology transfer, outreach, and educational networks.

Performance measures to track key activities representing these program objectives are discussed in Section 6.2 . 
WHC-EP-0496, Rev. 1

\subsection{GOALS}

P2 program goals achievable by December 1999 will be established in accordance with Executive Orders, DOE guidance, and the DOE Crosscut plan. These goals will be an aggregate of individual generator group goals and be based on 1993 pollutant release and generation rates.

The WHC Pollution Prevention organization will distribute goal setting guidance for individual generator groups early in FY 1995. The guidance will provide instruction on establishing goals achievable by December 1999 and annual goals to support the achievement of the 1999 goals. Pollution Prevention will also provide support to generators and generator groups in establishing their goals.

Generators and generator groups will have their five year and 1995 goals established by January 15, 1995. These goals will then be aggregated into WHC P2 program goals and be provided to RL to meet the commitment in the Site WMin/P2 plan of finalizing Site goals by January 31, 1995. After 1995, goals will be established annually by generators and generator groups and aggregated at the WHC P2 program level.

\subsection{IMPLEMENTATION SCHEDULES}

An implementation schedule of the sitewide program elements is presented in Appendix D. This schedule identifies the timetable for implementing programmatic requirements and elements identified in the Site WMin/P2 p1 an and in the DOE Crosscut plan. Detailed multi-year work plans will be developed annually by the organizations identified in Section 2.3 during the July through September program planning and budgeting period. : These work plans wi11 identify P2 schedules and funding for fiscal year activities.

\subsection{FUNDING}

Funding for the program is received through activity data sheets (ADS) and through overhead accounts. WHC P2 activities are funded predominately through ADSs. BCSR and ICF KH P2 activities are funded primarily through overhead accounts. Generators and generator groups have al so received funding from EM-334 to fund the development of special projects, sitewide initiatives, return-on-investment projects, technical assistance, and other program initiatives. EM-334 funding is expected to supplement WHC P2 Program funding through FY 1996.

A summary of program funding for FY 1994 through FY 1999 is provided as two tables in Appendix $E$. The information is broken down according to key sitewide and generator group program elements identified from the DOE Waste Minimization/Pollution Prevention Crosscut PIan. Table 1 provides summary funding information for sitewide WHC P2 program elements. This funding supports WHC Pollution Prevention and WHC Recycling. Table 2 identifies funding for generator groups, and for generator activities not included in Table 1. This funding supports al1 BCSR and ICF KH organizations with P2 responsibilities, and WHC generator groups. Generator and generator group funding data in Table 2 were extrapolated for the key program elements. 


$$
\text { WHC-EP-0496, Rev. } 1
$$

The program funding strategy is to establish separate, identifiable P2 funding for the sitewide and generator group program elements. Beginning in FY 1995, sitewide program activities (Table 1) will be identified in a separate P2 ADS. For generator and generator group activities identified in Table 2, the approach will be to have separate, identifiable P2 funding established by the beginning of FY 1996. Meeting this schedule will depend upon the modification of existing site funding structures to meet P2 program needs.

WHC Pollution Prevention will provide support and guidance to generators and generator groups as they identify and establish separate, identifiable funding. Priority will be given to funding P2OAs and implementation of opportunities. P2 program planning and budgeting will be in accordance with DOE planning and budgeting guidance. Separate, identifiable funding will help track P2 activities and allow the summation of dedicated WHC P2 program funding. It will also increase the visibility of P2. Program planning and budgeting activities will also involve identifying all the resources needed for full program implementation, comparing these identified resource needs with existing funding levels. For areas where funding does not match program needs, program personnel will work with contractor management and DOE to obtain increased funding.

\subsection{PERSONNEL}

Program personnel responsible for $\mathrm{P} 2$ have been identified across the Site. P2 has typically represented a small portion of their responsibilities. Program personnel will work with management to secure increased resources to support the identification and implementation of P2 opportunities and the implementation of an effective P2 program. This will be done primarily by Site program administration personnel actively participating with generator group $\mathrm{P} 2$ representatives and their management in the planning and budgeting process.

\subsection{OPERATING PROCEDURES}

Pollution prevention has been established in many WHC, BCSR, and ICF KH procedures. Many of these procedures are being updated to reflect the new program planning approach, and to emphasize the establishment of goals, priority activities and resource requirements, the performance of P2OAs, and the implementation of identified opportunities. Program requirements are being established in generator work control manuals and P2 in design is being established through DOE-RL Order 6430.1C (1990).

\subsection{QUALITY ASSURANCE}

WHC, BCSR, and ICF KH contractor management, with support from quality Assurance organizations, are responsible for implementing a quality WMin/P2 program. Management will ensure $\mathrm{P}_{2}$ activities are effectively conducted and documented in accordance with DOE Directive 5700.6C and Quality Assurance Programs. Independent assessment of the generator and generator group programs will be conducted to measure program quality and effectiveness. The organization performing independent assessments shall have sufficient authority and freedom from the line organizations to carry out its responsibilities. 


\subsection{EMPLOYEE INVOLVEMENT}

Employee involvement in pollution prevention has been increasing through establishing P2 in all applicable training courses and through awareness. The specific activities identified below have been planned to continue to increase employee involvement and raise awareness.

\subsection{TRAINING}

General P2 training is provided for all WHC, BCSR, and ICF KH personnel. The objectives of this training are to make each employee aware of P2, its impact on the Site and the environment, and ways waste can be reduced and pollution prevented. Each employee has general P2 training annually through Hanford General Employee Training and specific P2 training is provided in other Site training courses. Many of these courses are described in greater detail in the Site WMin/P2 plan. WHC Pollution Prevention will review at least six courses annually, and update them as needed.

\subsubsection{P20A Training}

The Pollution Prevention organization will provide specific P20A training for those groups involved in identifying and implementing P2 opportunities. The training will introduce participants to pollution prevention, describe the P2OA scope and process, and provide instruction for completing the P2OA worksheets. P2OA pilot training has been conducted in FY 1994. The training will be formally available beginning FY 1995.

\subsubsection{Training for Incorporating Pollution Prevention into Design}

A course exists to train facility designers, engineers, and project managers on methods to prevent pollution in project and new facility design. This course was developed in FY 1993 and finalized in FY 1994. It is sponsored by WHC and ICF KH and is available to Site personnel. Additional training will also be developed and become available in FY 1995 on specific design aspects. This training will be provided by individuals who have expertise in a particular area of design and pollution prevention.

\subsection{AWARENESS}

WHC participates in the Environmental Awareness Program through the Environmental Awareness Council. The council promotes environmental awareness through the pollution prevention awareness campaign and does this through using existing Site media channels.

The P2 program will also promote awareness through activities independent of the Environmental Awareness Council. Some of these awareness activities are the publishing of an annual Pollution Prevention Accomplishments book, exhibiting a Pollution Prevention display board at facilities across the Site, and printing articles twice a month in the Hanford Reach. Each of these awareness tools highlight significant Hanford P2 accomplishments.

An FY 1996 pollution prevention awareness activity will involve preparing and distributing a brochure. The brochure will contain information similar to 
WHC-EP-0496, Rev. 1

the accomplishments book, highlighting quantities of waste reduced or recycled, pollution prevented, energy conserved, and cost savings. The brochure will be handed out at conferences and used in conjunction with the display board. Other awareness activities will be planned and implemented as they are identified.

\subsection{INCENTIVES}

The Pollution Prevention group will recognize an individual or group's pollution prevention achievements through Hanford REACH articles and through the annual accomplishments book. Additionally, WHC, BCSR, and ICF KH employees are eligible for awards and recognition through DOE, Westinghouse Corporate, Site and contractor incentive campaigns and programs.

Site personnel are eligible for receiving awards from DOE at annual Pollution Prevention conferences where individuals are recognized for their outstanding P2 accomplishments. Some individuals from Hanford have already been recognized for their significant accomplishments. Pollution Prevention will continue to publicize and communicate WHC P2 program accomplishments to DOE for recognition of Site personnel.

Westinghouse Corporate Environmental Health and Safety Council sponsors a recognition program. Outstanding pollution prevention accomplishments by individuals, teams, or entire facilities can be recognized through this program. Achievements are featured in the Environmental Control Newsietter and may also be featured in periodic reports to shareholders, the media, and local communities. Award recipients also receive a memento to commemorate the environmental accomplishment.

WHC, BCSR, and ICF KH programs can promote the implementation of costeffective pollution prevention ideas. The Employing Consolidation \& Cost Effectiveness Leadership Program allows employees to present definite plans, actions, or changes in systems, policies, and practices that will improve the company product, process, or service. Participating employees receive recognition and cash awards for their cost saving improvements when implemented.

The WHC Great Ideas! suggestion program promotes employee input for improving the way their job or other jobs are performed. The program offers gifts including the possibility of a premium gift of a much higher value if the employee's idea results in "hard dollar" savings. In some cases, WHC Great Ideas! initatives also can be applied to the Employing Consolidation \& Cost Effectiveness Leadership Program.

An incentive campaign to promote paper recycling and the purchasing of products containing recycled material will be started in FY 1995. This campaign is a joint effort between WHC Pollution Prevention, WHC Recycling, and the Hanford Site Environmental Awareness Program. Employees who use their desktop recycling tray will receive a memento for their efforts. 


\subsection{TRACKING}

An important element of the $P 2$ program is to develop and implement effective tracking systems. These systems will track material inventories, waste streams, opportunity assessments and implementation, and cost. This will involve the modification of existing databases, such as the HMID2 and SWITS, and the development of new systems. The use of automated tracking systems represents a shift from past practice, where tracking of these activities was often performed manually.

\subsection{EMERGENCY PREPAREDNESS AND COMMUNITY RIGHT-TO-KNOW ACT MATERIAL INVENTORY TRACKING}

HMID2 is used to track hazardous materials and inventories at WHC, BCSR, and ICF KH facilities. For purposes of the P2 program, it will also be used to identify priority hazardous materials to reduce or eliminate. HMID2 is used to maintain current information on hazardous chemical and hazardous material inventories as defined by the Emergency Preparedness and Community Right-to-Know Act and the Occupational Safety and Health Administration Hazard Communications Standard. The overall architecture for HMID2 is based on a central host computer. Access to the host computer is through terminal emulation via the Hanford Local Area Network.

The HMID2 contains the necessary information for determining priority hazardous materials. These priority materials will become the targets of $P 2$ efforts. HMID2 information includes the following:

- Container size

- Container type

- Container unit of measure

- Facility identification

- Facility location - detailed information

- Facility name

- Material name

- Material local name

- MSDS identification

- Reporting representative identification

- Standard pressure

- Standard temperature

- Weight percent of hazardous components.

HMID2 does not currently provide an annual usage of material because materials are updated on a monthly basis and do not take into account daily usage changes. This database will be analyzed in FY 1995 to determine the ease and feasibility of modifying the system to identify annual usage. Annual usage information would be used to develop automated material use reports directly from HMID2. These reports would be used by generators and generator groups to identify priority materials to eliminate or reduce. If cost effective and funding is available, the system will then be modified to support the P2 program. 
WHC-EP-0496, Rev. 1

\subsection{WASTE TRACKING}

The SWITS is used to identify and track Hanford waste streams. The SWITS database provides a "Cradle to Grave" tracking system for the management of radioactive, hazardous, and mixed solid waste in support of generator group waste shippers, transporters, and storage personne7. SWITS also provides the Hanford site with a data management tool for delivering detailed regulatory compliance information to Federal, state, and local agencies.

SWITS waste tracking begins at the point of origin. The database collects unique information about each waste container and its contents, including details on physical components, isotopic quantities, and chemical constituents. Waste storage data contained in the SWITS database include container information, container location, and a barcode. Barcodes are used to provide automated facility inventories.

Beginning in FY 1995, SWITS will support the P2 program in four ways. First, it will be used to extract specific waste generator and generator group data for prioritizing waste streams by quantity, toxicity, and cost. Once priority streams are identified through SWITS, generators and generator groups can work "upstream" to identify the major activities producing the waste and perform opportunity assessments on these activities.

Second, it will be used in establishing P2 program performance indicators. The data will document waste reduction from P2 efforts by providing actual waste generation quantities for a given year to compare with waste forecasts for that year. Credit for waste reduction from $\mathrm{P} 2$ efforts will be adjusted for changes in operations and activities.

Third, SWITS will support the preparation of DOE and EPA waste generation and waste minimization reports. Standard reports are being coded into the system for data on waste generation to support reporting to DOE-HQ on the SEN 37-92 report. The system is current7y being modified to include some data elements required by the EPA for the Biennial Waste Minimization Report submitted with the WAC 173-303 Dangerous Waste Report.

Fourth, SWITS will provide baseline waste generation data. The baseline will help in establishing priority generator and generator group waste streams to reduce, and be used to measure program progress against. The baseline year will be 1993. SWITS will be explored further to determine additional ways the system can support the P2 program.

\subsection{OPPORTUNITY ASSESSMENT TRACKING}

A P20A tracking system to identify P20A progress, results, and activities' assessments have been performed on will be developed in FY 1994 and FY 1995 and implemented the end of FY 1995. Through the use of this database and SWITS, information requested from generators and generator groups for annual reporting purposes should be minimized or el iminated. Information required for compliance and DOE reports will be taken directly from the database.

The P20A database will also provide a tool for information exchange by providing key word search capabilities for P20As already conducted. A listing of these P20As will be provided on the Hanford Information software so other 
generator group programs conducting P20As on similar activities can view opportunities identified or obtain copies of completed P20As. The system will also identify resource requirements and cost benefits for implementation of P2 opportunities.

\subsection{COST TRACKING AND ACCOUNTING}

\subsubsection{Cost Tracking}

A tracking system will be developed in FY 1995 to track annual WHC P2 program costs. The system will contain summary information for generator and generator group programs. The information from the cost tracking system will be used in the Annual DOE Report on Waste Generation and Waste Minimization Progress and for program management.

\subsubsection{Cost Accounting}

Many of the costs and benefits associated with environmental management and $\mathrm{P2}$ are not readily apparent. The WHC P2 program will work to ensure WHC personnel associated with polluting and waste generating activities have complete information on the full costs and benefits associated with these activities. This will be done primarily through "life-cycle" cost evaluations of options generated from opportunity assessments.

The Waste Cost Avoidance Model is a tool being developed by the DOE to be used throughout the DOE complex. It will be used to estimate a "life-cycle" cost of waste generation, treatment, storage and disposal at the different sites. The total cost per quantity for each waste type and treatability group will be used in evaluation of pollution prevention initiatives through comparing cost savings and payback periods of different initiatives.

The main benefit of this model is to allow generator groups to determine which projects are the most cost-effective. Waste cost avoidance will be a used as a justification for funding P2 projects. Additionally, waste cost analysis will help to quantify the total effects of proposed or implemented P2 opportunities and give those who develop initiatives a strong technical and financial basis for promoting their idea. The waste cost avoidance model will be available for site use once the final report on the model is issued by the DOE, which is expected in FY 1995. 
WHC-EP-0496, Rev. 1

\subsection{REPORTING}

\subsection{CONPLIANCE REPORTING}

The WHC P2 program information reported is a consolidation of WHC, BCSR, and ICF KH P2 program activities. ICF KH Environmental Program and Integration consolidates their generator group information and submits summary information to WHC Pollution Prevention on their P2 activities. BCSR submits their information to WHC as one generator. WHC Pollution Prevention consolidates the WHC P2 program information with other Site contractor program information for the different required reports.

Results of the WHC P2 program are reported to the EPA and Washington State Department of Ecology (Ecology). The Biennial Report on Waste Minimization is sent on even years to the two agencies. In addition to the Biennial report, program activities are also reported in other documents. Some of these are the annual Land Disposal Restrictions Federal Facilities Compliance Act report, the Emergency Planning and Community Right-to-Know Act, Section 313 report, an affirmative procurement progress report, and the Office of Management and Budget, Circular A106, Federal Agency Pollution Abatement Plan.

In accordance with RL's voluntary commitment to comply with WAC 173-307, the WHC P2 program provided input for and coordinated the preparation and submittal of the 1992 Hanford Site Pollution Prevention Plan. The Executive Summary of the plan was sent to Ecology and for follow-up WHC, BCSR, and ICF $\mathrm{KH}$ are required to submit an annual pollution prevention progress report to Ecology each September.

In 1994, Pollution. Prevention introduced a new approach to Ecology to comply with WAC 173-307. This approach takes into account comments received by Ecology review of the 1992 plan Executive Summary, and represents the streamlined approach to pollution prevention planning described in Section 3.2 of this plan. Generator groups will prepare program documentation of their goals, budget, P20As, and progress reports. General information about generator group P2 programs is located in the WHC P2 program Plan and the Site program plan. Ecology concurred with this new approach. WHC Pollution Prevention will send progress reports each September to Ecology on site P2 program planning and progress. In 1997, WHC Pollution Prevention will update the Site plan Executive Summary and submit it to Ecology.

\subsection{REPORTS TO THE U.S. DEPARTMENT OF ENERGY}

The WHC P2 program provides input to and coordinates the preparation of Site input for the DOE Annual Report on Waste Generation and Waste Minimization Progress. This report provides program managers, site program personnel, and the public with important information on current waste generation and waste minimization at the DOE Sites. Originally mandated by Secretary of Energy Notice (SEN-37-92) (DOE 1992b), each site is required to provide information on their waste generation broken down by ten waste types. Sitewide waste minimization activities and facility-specific waste

minimization activities and information is also required, including goals and budget. 


\subsection{SITEWIDE WASTE REDUCTION}

\subsection{TOXICS REDUCTION/MATERIAL SUBSTITUTION}

The Hazardous Materials Reduction Initiative, a centralized system for controlling the procurement of hazardous chemicals, was implemented in FY 1994. The hazardous chemicals to be controlled include those identified in the original and expanded EPA 33/50 1 ist, a 11 ozone-depleting substances included in the Montreal Protocol 1ist, and other EPA and State identified hazardous chemicals. No precedence or priority is established for eliminating one hazard over another; all hazardous chemicals will be reviewed for product substitution of less hazardous products.

Each request for hazardous materials is reviewed to determine if a less hazardous substitute may be used or if locally excessed materials are available. A byproduct of this system is the development of a product substitution database that will help speed the substitution process. This database can be shared with other contractors once it has been more fully developed. The system will be available for use late in FY 1994 and be available for use by other Site contractors in FY 1995.

Also, ICF KH is pursuing the cost-effectiveness and feasibility of substituting the chlorine used for potable water treatment with a less hazardous potable water treatment product. Findings from the effort will be used to meet the 100 percent chlorine reduction goal identified in Appendix $B$ of the Site WMin/P2 plan.

\subsection{MATERIAL EXCHANGE}

The Chemical Redeployment program coordinates material exchange at the site. The program has been very successful redeploying used chemicals. Most of the Site large bulk tank chemicals and concentrated chemicals have been redeployed in FY 1994. This activity will continue in FY 1995. Also, the redeployment of small. quantity chemicals is growing as evidenced by the first janitorial supply sale completed late in FY 1994. To support this effort, the program is developing a catalog to be distributed onsite that contains a listing of available chemicals. This catalog will be available in FY 1996.

\subsection{RECYCLING/REUSE}

The recycling program has a very successful paper recycling program with 100 percent of all eligible buildings participating. The program is also expanding the recycling of other materials. By the end of FY 1994, a scrap wood laydown yard will be developed. Wood will be selectively collected in FY 1995 and 1996, as Site personnel become educated on what wood will be accepted for redeployment. The wood recycling program will be fully functioning by the middle of FY 1997.

Cardboard recycling is also growing. In addition to the large Stores receiving warehouse, the program now collects cardboard from several other large generator groups. All significant cardboard waste generator groups are expected to be participating in the cardboard recycling program by the end of FY 1996. 


\subsection{AFFIRMATIVE PROCUREMENT}

As a procurement control mechanism, WHC has initiated two affirmative procurement clauses in their contracts with suppliers to support the purchase of recycled materials (WHC 1994b). The first clause asks suppliers whether their products are recyclable or if they contain recycled content. The second clause requires information on the five categories of products for which the Environmental Protection Agency has established minimum content standards. The categories are paper products, insulation products, cement and cement products, lubricating oils, and tires. Recycled content information is required for these products. Proposals for products that do not meet the minimum content standard may be ineligible for award.

Specific guidance has also been provided to WHC Procurement by Pollution Prevention to help them in the implementation of Executive Order 12843, Procurement Requirements and Policies for Ozone-Depleting Substances, issued 1993, which requires Federal agencies to minimize the procurement of Class I ozone-depleting substances. This guidance directs buyers to review all purchase requests for equipment that may potentially contain such a substance and seek vendors who can supply equivalent equipment with alternative refrigerants. It also advises Procurement to limit the distribution of store stock items containing Class I ozone-depleting substances to service and operating groups that can demonstrate a need for that material. 


\subsection{TECHNICAL ASSISTANCE}

Technical assistance will be provided to generators and generator groups to assist the development and implementation of their individual P2 programs. Consistent assistance provided in accordance with this plan and established program guidance manuals will support the development of consistent P2 programs. Technical assistance will be provided for the following priority program areas and other program priorities as they are identified in the future.

\subsection{GOAL SETTING}

A goal setting methodology has been developed in FY 1994. This methodology will be contained in the program documentation guidance manual discussed in Section 3.2 of this plan. The goal setting guidance encourages generator groups to analyze pollutant releases, waste streams generated, and hazardous material use in their activities. Using this methodology, generator groups will be able to identify their priority hazardous materials, waste types, pollutants to reduce or eliminate. They will set quantitative goals on the reduction of these materials and streams, and establish schedules and activities to achieve these goals. Goals will provide a basis for establishing resource requirements for generator group programs.

\subsection{BASELINE DETERMINATION}

A program waste generation baseline was established in Fy 1994. This information was taken from SWITS and the Solid Waste Projections Model. Baselines and projections at the generator, generator group, and WHC P2 Program level will be used to track program progress and to annually identify priority waste generating activities. Chemical inventories will also be used to establish baseline information on hazardous chemical use.

\subsection{OPPORTUNITY ASSESSMENTS}

A P20A (formerly Process Waste Assessment) is the primary mechanism used for identifying and analyzing activities for P2 opportunities, and provides the basis for developing and prioritizing P2 options. These assessments on polluting and waste generating activities are performed by a team of individuals selected for their process knowledge, purchasing and material inventory knowledge, regulatory, and P2OA expertise. Individuals with expertise in other areas may be added to the team depending on the nature of the process being assessed.

Development of a WHC P2OA methodology was initiated in 1993. In 1994, pilot-scale testing of the adaptable $P 20 A$ process was completed. Lessons learned from the pilot-scale testing were incorporated into the finalized P20A process. Full-scale conducting of P20As will begin in FY 1995. P20As will be continually conducted during P2 program implementation.

Guidance and training has been developed by the Pollution Prevention organization to support P2OA implementation. In general, the guidance and training explain how to identify and prioritize hazardous materials and waste streams, set goals, select a team, brainstorm ideas, rank P2 initiatives, and 
begin implementation. The guidance is consistent with the objectives of $D O E$ guidance, the EPA Waste Minimization Opportunity Assessment Manual (EPA 1989), and the WAC 173-307. The training and guidance will be updated annually or as needed.

\subsection{MODEL PROGRAMS}

The WHC P2 program has and will continue to incorporate program activities developed under model pollution prevention programs within the DOE complex. The WHC P2 program has taken mode1 P2OA worksheets and information developed at the Kansas City DOE Site and adapted them for use at Hanford. Additionally, program personnel will strive to continue to develop and implement a model program here at Hanford that is based on the key Sitewide and generator group program elements identified in the crosscut plan.

\subsection{PROGRAM ACTIVITY TRACKING}

Generators and generator groups track their pollution prevention activities and submit quarterly and annual reports on progress in achieving their annual goals and in implementing opportunities identified in from the conducting of their P20As. WHC P2 Program management personnel will track these program activities to assist generators and generator groups in measuring program progress and to support the implementation of identified pollution prevention opportunities. 
WHC-EP-0496, Rev. 1

\subsection{INFORMATION AND TECHNOLOGY EXCHANGE}

\subsection{SEMINARS, WORKSHOPS, AND MEETINGS}

Meetings with generator and generator group P2 program coordinators will be held at least quarterly to update coordinators on program activities, management direction, and new program requirements. These meetings will also be a forum for technology exchange within the Site. Technical presentations on P2 techniques will be shared and coordinators can also describe activities they are performing and results they are seeing from their efforts.

\subsection{INFORMATION CLEARINGHOUSE}

All program staff are encouraged to make regular use of the DOE Energy Pollution Prevention Information Clearinghouse and the EPA Pollution Prevention Information Exchange System. Additionally, personnel will also attend DOE workshops and other forums or conferences to exchange information.

A WHC P2 program representative also participates in information exchange through the Westinghouse Government-Owned, Contractor-Operated (GOCO)

Pollution Prevention Subcommittee. This committee has been established to promote and facilitate the sharing of pollution prevention information between Westinghouse GOCOs and commercial business units. This includes providing technical and program expertise to GOCO sites on pollution prevention problem solving and on implementing new DOE and regulatory requirements. Also, subcommittee meetings serve as a forum for discussing pollution prevention program status and issues for each site. The WHC P2 program will share methodologies developed at Hanford and significant program accomplishments with representatives on this subcommittee. Applicable information received from other subcommittee representatives will be used to enhance the WHC P2 program.

Also, another important medium to aid information exchange is the P2OA tracking system being developed in FY 1995. Generators and generator groups will be able to search this database for specific information important to their individual activities. A more detailed description of this tracking system is provided in Section 5.3.

\subsection{OUTREACH AND PUBLIC RELATIONS}

Communicating pollution prevention successes and information to the community through outreach. and public involvement will assist in establishing public confidence and trust, increase awareness of environmental issues, and promote the reduction of waste. The WHC P2 program will participate in the organizing of activities such as Earth Day, the local schools' Ambassadors program, WHC Sharing Conferences, and Auto Earth Day, and also publish information externaliy to help increase awareness and public trust.

Additionally, public and stakeholder participation will be sought for applicable projects and program elements to encourage community involvement and develop a broad base of input and understanding of relevant pollution prevention issues. 
WHC-EP-0496, Rev. 1

\subsection{RESEARCH AND DEVELOPMENT}

Proposals for research and development are expected to arise from the pollution prevention opportunity assessment process described in Section 8.2. Specific proposals for research and development work will be coordinated through RL and DOE-HQ to ensure effective allocation of resources. 


\subsection{PROGRAM EVALUATION}

\subsection{EMPLOYEE PARTICIPATION}

Formal employee evaluation of the program is performed through training evaluations and through evaluations completed by generator group P2 program coordinators. Employees complete an evaluation after Hanford General Employee Training and P20A training. Valuable comments have been received and the training modules have been improved based upon the comments. Training will continue to be improved based on employee input.

Generator group P2 program coordinators participated in a program evaluation in 1992. The evaluation identified a number of areas where the program could be strengthened. Some of these included developing additional or more effective ways to increase awareness, provide more field training to personnel on how to identify and implement P2 opportunities, obtain increased funding for program activities, and reduce the emphas is on reporting and paperwork. Coordinators will continue to have the opportunity to formally evaluate the program at least annually.

\subsection{POLLUTANT AND WASTE REDUCTION PERFORMANCE}

Three program performance measures will be established annually and submitted to the RL Pollution Prevention Program Manager for approval. Performance measures will be used to track key activities and progress against them. These measures will provide a basis for program evaluation.

Pollutant and waste reduction performance will be evaluated through comparing waste, pollutant, and hazardous material reduction results with goals and 1993 baselines. This evaluation will be performed annually at the generator and generator group level.

\subsection{PROGRAM IMPLEMENTATION}

The WHC P2 program will be evaluated semi-annually. Achievements and milestones in the program will be a part of WHC's performance evaluation and determination of award fees. All major activities will be reviewed. The evaluation will document program achievements and identify potential areas for improvement. The success criteria in the Site WMin/P2 plan will be used in evaluating $P 2$ efforts. 
WHC-EP-0496, Rev. 1

This page intentionally left blank. 


\subsection{REFERENCES}

DOE, 1988, General Environmental Protection Program, DOE Order 5400.1, U.S. Department of Energy, Washington, D.C.

DOE, 1992, Waste Minimization Crosscut Plan Implementation, Secretary of Energy Notice (SEN-37-92), issued May 13, U.S. Department of Energy, Washington, D.C.

DOE, 1994a, Guidance for Preparation of Site Waste Minimization and Pollution Prevention Awareness P7ans, U. S. Department of Energy, Washington, D.C.

DOE, 1994b, Waste Minimization/Pollution Prevention Crosscut Plan, U.S Department of Energy, Washington, D.C.

DOE-RL, 1990, Hanford Plant Standards Program, DOE/RL 6430.1C, U.S. Department of Energy, Richland, Washington.

DOE-RL, 1994a, Hanford Site Waste Minimization and Pollution Prevention Awareness Program PIan, DOE/RL-91-31, Rev. 1, U.S. Department of Energy, Richland, Washington.

DOE-RL, 1994b, Pollution Prevention Policy for Richland Operations, (letter, May 6), U.S. Department of Energy, Richland, Washington.

DOE-RL, 1994c, Guidance on the Management of Office Waste, (1etter, June 16), U.S. Department of Energy, Richland, Washington.

Emergency Planning and Community Right-to-Know Act, as amended, 42 USC 11013, 11028, et seq.

EPA, 1989, Waste Minimization Opportunity Assessment Manual, EPA/625/7-88/003, U.S. Environmental Protection Agency, Washington, D.C.

Executive Order 12843, 1993, "Procurement Requirements and Policies for OzoneDepleting Substances," Federal Register, Vol. 58, pp. 21881, (Aprii).

Executive Order 12856, 1993, "Federal Agency Compliance with Right-toKnow Laws and Poilution Prevention Requirements," Federal Register, Vol. 58, pp. 41981, (August).

Executive Order 12873, 1993, "Federal Acquisition, Recycling and Waste Prevention," Federal Register, Vol. 58, pp. 54911, (October).

Executive Order 12902, 1993, "Energy Efficiency and Water Conservation at Federal Facilities," Federal Register, Vo1. 58, pp. 11463, (March).

Federal Facility Compliance Act of 1992, as amended, Public Law 102, 386.

Resource Conservation and Recovery Act of 1976, as amended, 42 USC 6901 et seq. 
WHC-EP-0496, Rev. 1

WAC 173-303, 1991, "Dangerous Waste Regulations," Washington Administrative Code, as amended.

WAC 173-307, 1991, "Hazardous Waste Facilities P1ans," Washington Administrative Code, as amended.

WHC, 1992, Waste Generating Policy, (Internal memo, R.J. Landon, November 25), Westinghouse Hanford Company, Richland, Washington.

WHC, 1994a, Guide for Preparing and Maintaining Generator Group Pollution Prevention Program Documentation, WHC-SD-WM-EV-014, Rev. 2, Westinghouse Hanford Company, Richland, Washington.

WHC, 1994b, The Reduction of Packaging Waste, WHC-MR-0448, Westinghouse 
WHC-EP-0496, Rev. 1

APPENDIX A

U.S. ENVIRONMENTAL PROTECTION AGENCY

WASTE MINIMIZATION PROGRAM ELEMENTS GUIDANCE COMPLIANCE MATRIX 
WHC-EP-0496, Rev. 1

WHC-EP-0496, Rev. 1

WHC-EP-0496, Rev. 1 
U.S. ENVIRONMENTAL PROTECTION AGENCY

WASTE MINIMIZATION PROGRAM ELEMENTS GUIDANCE COMPLIANCE MATRIX

\begin{tabular}{|c|c|}
\hline $\begin{array}{c}\text { EPA GUIDANCE } \\
\text { WASTE MINIMIZATION PROGRAM ELEMENTS } \\
\text { (Resource Conservation and Recovery } \\
\text { Act of 1976) }\end{array}$ & PROGRAM DOCUMENTATION \\
\hline \multicolumn{2}{|l|}{ A. TOP MANAGEMENT SUPPORT } \\
\hline Company policy & Contractor plans \\
\hline Goals & $\begin{array}{l}\text { Hanford Site plan, Contractor plans } \\
\text { Generator group program } \\
\text { documentation }\end{array}$ \\
\hline $\begin{array}{l}\text { Commitment - opportunity } \\
\text { implementation }\end{array}$ & Hanford Site plan, Contractor plans \\
\hline Facility coordinator & Contractor plans \\
\hline Publicize successes & Hanford Site plan, Contractor plans \\
\hline Incentives & Hanford Site plan, Contractor plans \\
\hline Training & Hanford Site plan, Contractor plans \\
\hline $\begin{array}{l}\text { B. CHARACTERIZATION OF WASTE } \\
\text { GENERATION }\end{array}$ & Contractor plans \\
\hline \multicolumn{2}{|l|}{ C. OPPORTUNITY ASSESSMENTS } \\
\hline Identify al1 opportunities & $\begin{array}{l}\text { Contractor plans } \\
\text { Generator group program } \\
\text { documentation }\end{array}$ \\
\hline Determine true costs of the waste & $\begin{array}{l}\text { Contractor plans } \\
\text { Generator group program } \\
\text { documentation }\end{array}$ \\
\hline D. COST ALLOCATION SYSTEM & Hanford Site plan, contractor plans \\
\hline E. TECHNOLOGY TRANSFER & Hanford Site plan, contractor plans \\
\hline F. PROGRAM EVALUATION & $\begin{array}{l}\text { Hanford Site plan, contractor plans } \\
\text { Generator group program } \\
\text { documentation }\end{array}$ \\
\hline
\end{tabular}

Federal Register, Vol. 58, No. 102, 1993.

Resource Conservation and Recovery Act of 1976, as amended, 42 USC 6901 et seq. 
WHC-EP-0496, Rev. 1

This page intentionally left blank. 
WHC-EP-0496, Rev. 1

APPENDIX B

GENERATOR GROUP P2 PROGRAM DOCUMENTATION 
WHC-EP-0496, Rev. 1

This page intentionally left blank. 
WHC-EṔ-0496, Rev. 1

\section{GENERATOR GROUP P2 PROGRAM DOCUMENTATION}

Goals on Waste Types, Pollutants, and Hazardous Chemicals

- Five year forecast and annual goals

- Source reduction

- Recycling

- Pollution prevention opportunity assessments

- Environmental Compliance Officer and Senior management signatures

Separate, Identifiable Budget, Activities and Schedule

- Budget supporting P2 activities, deliverables, and milestones

Pollution Prevention Opportunity Assessments and Implementation

- Summary waste stream prioritization information

- Waste stream information

- Priority waste streams and activities

- Pollution prevention opportunity assessment

- Team and activity description

- Activity flow diagram

- Pollution prevention opportunity description

- Pollution prevention opportunities summary

- Final summary

\section{Pollution Prevention Reporting}

- Quarterly reports (3)

- Status on goals

- Report on accomplishments and P20A implementation progress

- Senior management signature

- Annual report

- Status on achieving annual goals

- Status on meeting (or adjustments to) five year forecast

- Next calendar year goals

- Facility Waste Reduction Form

A. Annual certification with senior management signature

B. Waste reduction on specific waste streams 
WHC-EP-0496, Rev. 1

This page intentionally left blank. 
WHC-EP-0496, Rev. 1

APPENDIX C

WESTINGHOUSE HANFORD COMPANY

POLLUTION PREVENTION AND WASTE MINIMIZATION POLICY 
WHC-EP-0496, Rev. 1

This page intentionally left blank. 
WHC-CM-1, Company Policies and Charters

Rev. 0

May 26, 1994

Pollution Prevention and Waste Minimization Policy

We will conduct our operations and activities in a way that minimizes the quantity and toxicity of wastes generated, eliminates or minimizes pollutant releases to the environment, and minimizes the use of toxic substances. This will be done through better design, product acquisition, and changes in technologies, work practices, and procedures.

We are committed to operating an effective pollution prevention (P2) program (formerly known as the waste minimization program). The WHC P2 program priorities in descending order are:

1. Source reduction

2. Environmentally safe recycling

3. Waste treatment

4. Environmentally safe disposal.

Waste treatment to reduce the quantity, toxicity, or mobility (or a combination of these) will be considered only when prevention or recycling are not possible or practical. Environmentally safe disposal is the last option.

The WHC P2 program will comply with the letter and the spirit of current and future waste minimization and pollution prevention executive orders, regulatory requirements, and DOE directives. The program will be based upon the program elements identified in the 1994 Department of Energy Waste Minimization/Pollution Prevention Crosscut Plan and emphasize establishing goals, performing pollution prevention opportunity assessments, and implementing identified opportunities. Opportunities will be implemented whenever technically and economically practicable and whenever risks will not be shifted from one environmental medium to another.

Management will provide adequate personnel, budget, training, and material to achieve these goals and implement a successful P2 program. The program will be documented in the P2 program plan and facilityspecific plans. Waste minimization and pollution prevention will become an integral part of the way work is performed at the Hanford Site. 
WHC-EP-0496, Rev. 1

This page intentionally left blank. 
WHC-EP-0496, Rev. 1

APPENDIX D

HANFORD SITE WMIN/P2 PROGRAN

REQUIREMENTS IMPLEMENTATION SCHEDULE

D-1 
WHC-EP-0496, Rev. 1

This page intentionally left blank. 


\begin{tabular}{|c|c|c|c|}
\hline \multicolumn{4}{|c|}{$\begin{array}{l}\text { HANFORD SITE WMIN/P2 PROGRAM } \\
\text { REQUIRENENTS IMPLEMENTATION SCHEDULE }\end{array}$} \\
\hline $\begin{array}{l}\text { CONTRACTOR } \\
\text { REQUIREMENT }\end{array}$ & $\begin{array}{l}\text { IMPLEMENTED? } \\
\text { (YES, NO, } \\
\text { PARTIAL) }\end{array}$ & $\begin{array}{c}\text { SCHEDULED } \\
\text { IMPLEMENTATION }\end{array}$ & DOCUMENTED \\
\hline $\begin{array}{l}\text { ORGANIZATION AND } \\
\text { INFRASTRUCTURE } \\
\text { - Program Integration/ } \\
\text { - Coordinator Network } \\
\text { Participate in DOE } \\
\text { - Program } \\
\text { Program Organization } \\
\text { and Responsibilities } \\
\end{array}$ & $\begin{array}{l}\text { YES } \\
\text { YES } \\
\text { PARTIAL }\end{array}$ & $\begin{array}{l}\text { ONGOING } \\
\text { ONGOING } \\
\text { ONGOING }\end{array}$ & $\begin{array}{l}\text { WHC PLAN } \\
\text { WHC PLAN } \\
\text { WHC PLAN }\end{array}$ \\
\hline $\begin{array}{l}\text { PROGRAM DEVELOPMENT } \\
\text { - Contractor Policy } \\
\text { - WHC P2 Program } \\
\text { Planning } \\
\\
\text { - Strategy, Objectives and } \\
\text { - Goals } \\
\text { - Buplementation Schedule } \\
\text { - Personnel Resource Reqts } \\
\text { - Operating Procedures } \\
\text { - Quality Assurance } \\
\end{array}$ & \begin{tabular}{|l} 
\\
PART IAL \\
YES \\
PARTIAL \\
PARTIAL \\
PARTIAL \\
YES \\
\end{tabular} & $\begin{array}{l}\text { ANNUALLY, } 7 / 97 \\
\\
1 / 95, \text { ANNUALLY } \\
\text { ANNUALLY } \\
\text { ANNUALLY } \\
1 / 96 \\
10 / 94 \\
8 / 94, \text { ANNUALLY }\end{array}$ & $\begin{array}{l}\text { WHC PLAN, WHC- } \\
\text { CM-1 } \\
\text { SITE/WHC PLAN, } \\
\text { GENERATOR GROUP } \\
\text { PROGRAM } \\
\text { DOCUMENTATION } \\
\text { (GPPD) } \\
\text { WHC PLAN, GPPD } \\
\\
\text { WHC PLAN, GPPD } \\
\text { WHC PLAN, GPPD } \\
\text { WHC PLAN, GPPD } \\
\text { CMS 1-5 \& 7-5 } \\
\text { WHC PLAN, GPPD }\end{array}$ \\
\hline $\begin{array}{l}\text { EMPLOYEE INVOLVEMENT } \\
\text { - Training } \\
\text { - General Employee } \\
\text { - P2OA } \\
\text { - P2 in Design } \\
\text { - Awareness } \\
\text { - Incentives } \\
\end{array}$ & \begin{tabular}{|l} 
YES \\
PARTIAL \\
YES \\
PARTIAL \\
YES \\
\end{tabular} & $\begin{array}{l}\text { ONGOING } \\
10 / 94 \\
4 / 95 \\
\text { ONGOING } \\
\end{array}$ & $\begin{array}{l}\text { SITE PLAN } \\
\text { WHC PLAN } \\
\text { WHC PLAN } \\
\text { WHC PLAN } \\
\text { WHC PLAN }\end{array}$ \\
\hline $\begin{array}{l}\text { TRACKING } \\
\text { - EPCRA Material Inventory } \\
\text { - Waste Tracking } \\
\text { - Opportunity Assessments } \\
\text { - Cost Accounting } \\
\end{array}$ & $\begin{array}{l}\text { PARTIAL } \\
\text { PARTIAL } \\
\text { NO } \\
\text { PARTIAL } \\
\end{array}$ & $\begin{array}{l}9 / 95 \\
9 / 95 \\
9 / 95 \\
9 / 95 \\
\end{array}$ & $\begin{array}{l}\text { WHC PLAN, HMID2 } \\
\text { WHC PLAN, SWITS } \\
\text { WHC PLAN } \\
\text { WHC PLAN }\end{array}$ \\
\hline $\begin{array}{l}\text { REPORTING } \\
\text { - Compliance Reporting } \\
\text { - Reports to DOE }\end{array}$ & $\begin{array}{l}\text { YES } \\
\text { YES }\end{array}$ & $\begin{array}{l}\text { ANNUAL, } \\
\text { BIENNIAL } \\
\text { ANNUAL }\end{array}$ & $\begin{array}{l}\text { WHC PLAN, GPPD } \\
\text { REPORTS } \\
\text { WHC PLAN, GPPD } \\
\text { REPORTS }\end{array}$ \\
\hline
\end{tabular}


WHC-EP-0496, Rev. I

\begin{tabular}{|c|c|c|c|}
\hline $\begin{array}{l}\text { SITEWIDE WASTE REDUCTION } \\
\text { - Toxics Reduction } \\
\text { - Material Substitution } \\
\text { - Material Exchange } \\
\text { - Recycl ing/Reuse } \\
\text { - Affirmative Procurement }\end{array}$ & \begin{tabular}{|l} 
PARTIAL \\
PARTIAL \\
YES \\
YES \\
YES \\
\end{tabular} & $\begin{array}{l}\text { ONGOING } \\
\text { ONGOING } \\
\text { ONGOING } \\
\text { ONGOING } \\
\text { ONGOING }\end{array}$ & $\begin{array}{l}\text { SITE, WHC PLAN } \\
\text { SITE, WHC PLAN } \\
\text { SITE, WHC PLAN } \\
\text { SITE, WHC PLAN } \\
\text { SITE, WHC PLAN }\end{array}$ \\
\hline $\begin{array}{l}\text { OPPORTUNITY ASSESSMENTS } \\
\text { - Evaluate Activities } \\
\text { ID and Prioritize } \\
\text { Opportunities } \\
\text { ID R\&D Needs } \\
\end{array}$ & $\begin{array}{l}\text { PARTIAL } \\
\text { PARTIAL } \\
\text { PARTIAL }\end{array}$ & $\begin{array}{l}\text { ONGOING } \\
\text { ONGOING } \\
\text { ONGOING }\end{array}$ & $\begin{array}{l}\text { GPPD } \\
\text { GPPD } \\
\text { GPPD }\end{array}$ \\
\hline $\begin{array}{l}\text { OPPORTUNITY } \\
\text { IMPLEMENTATION } \\
\text { - Process Modifications } \\
\text { - Material Substitutions } \\
\text { - Capital Expenditures } \\
\text { - R\&D, Demonstration } \\
\end{array}$ & $\begin{array}{l}\text { PARTIAL } \\
\text { PARTIAL } \\
\text { PARTIAL } \\
\text { PARTIAL } \\
\end{array}$ & $\begin{array}{l}\text { ONGOING } \\
\text { ONGOING } \\
\text { ONGOING } \\
\text { ONGOING }\end{array}$ & $\begin{array}{l}\text { GPPD } \\
\text { GPPD } \\
\text { GPPD } \\
\text { GPPD } \\
\end{array}$ \\
\hline $\begin{array}{l}\text { DESIGN CONSIDERATIONS } \\
\text { - New Facilities } \\
\text { - Facility and Process } \\
\text { Modifications } \\
\text { - New Technology } \\
\end{array}$ & $\begin{array}{l}\text { PARTIAL } \\
\text { PARTIAL } \\
\text { PARTIAL }\end{array}$ & $\begin{array}{l}\text { ONGOING } \\
\text { ONGOING } \\
\text { ONGOING }\end{array}$ & $\begin{array}{l}\text { SITE PLAN, GPPD } \\
\text { SITE PLAN, GPPD } \\
\text { SITE PLAN }\end{array}$ \\
\hline $\begin{array}{l}\text { TECHNICAL ASSISTANCE } \\
\text { - Goal Setting } \\
\text { - Technology Application } \\
\text { Assistance } \\
\text { - Basel ine Determination } \\
\text { - Opportunity Assessment } \\
\text { Support } \\
\text { - Model Programs }\end{array}$ & \begin{tabular}{|l} 
PARTIAL \\
YES \\
YES \\
PARTIAL \\
PARTIAL
\end{tabular} & $\begin{array}{l}1 / 95, \text { ANNUALLY } \\
\text { ONGOING } \\
10 / 94, \text { ANNUALLY } \\
\text { ONGOING }\end{array}$ & $\begin{array}{l}\text { SITE \& WHC PLAN } \\
\text { WHC PLAN } \\
\text { WHC PLAN } \\
\text { WHC PLAN } \\
\text { WHC PLAN }\end{array}$ \\
\hline $\begin{array}{l}\text { INFORMATION/TECHNOLOGY } \\
\text { EXCHANGE } \\
\text { Seminars, Workshops, } \\
\text { Meetings } \\
\text { Information Clearinghouse } \\
\text { - Outreach and Public } \\
\text { Relations }\end{array}$ & $\begin{array}{l}\text { PARTIAL } \\
\text { NO } \\
\text { YES }\end{array}$ & $\begin{array}{l}\text { 10/94, QTRLY } \\
\text { ONGOING } \\
\text { ONGOING }\end{array}$ & $\begin{array}{l}\text { WHC PLAN } \\
\text { WHC PLAN } \\
\text { SITE PLAN }\end{array}$ \\
\hline $\begin{array}{l}\text { PROGRAM EVALUATION } \\
\text { - Employee Participation } \\
\text { - Waste Reduction } \\
\text { Performance } \\
\text { - Program Implementation }\end{array}$ & $\begin{array}{l}\text { PARTIAL } \\
\text { PARTIAL } \\
\text { PARTIAL }\end{array}$ & $\begin{array}{l}\text { 1/95, ANNUALLY } \\
9 / 95, \text { ANNUALLY } \\
2 / 95, \text { EVERY } 6 \\
\text { MONTHS AFTER }\end{array}$ & $\begin{array}{l}\text { WHC PLAN } \\
\text { WHC PLAN } \\
\text { WHC PLAN, AWARD } \\
\text { FEE }\end{array}$ \\
\hline
\end{tabular}


WHC-EP-0496, Rev. 1

\author{
APPENDIX E \\ WESTINGHOUSE HANFORD COMPANY \\ POLLUTION PREVENTION PROGRAM FUNDING
}

E-1 
WHC-EP-0496, Rev. 1

This page intentionally left blank. 
WHC-EP-0496, Rev. 1

Table 1

WESTINGHOUSE HANFORD CONPANY

POLLUTION PREVENTION PROGRAM

SITENIDE ELEMENTS

\begin{tabular}{|c|c|c|c|c|c|c|}
\hline \multirow{2}{*}{$\begin{array}{l}\text { KEY SITEWIDE } \\
\text { PROGRAM ELEMENT } \\
\text { FISCAL YEAR }\end{array}$} & \multicolumn{6}{|c|}{ FUNDING LEVEL (\$K) } \\
\hline & 1994 & 1995 & 1996 & 1997 & 1998 & 1999 \\
\hline $\begin{array}{l}\text { Organization and } \\
\text { Infrastructure }\end{array}$ & $\begin{array}{r}16 \\
* 2 \\
\end{array}$ & $\begin{array}{r}51 \\
(70) \\
\end{array}$ & $\begin{array}{l}55 \\
(70) \\
\end{array}$ & $\begin{array}{r}55 \\
(70) \\
\end{array}$ & $\begin{array}{r}92 \\
(36) \\
\end{array}$ & $\begin{array}{c}95 \\
(36) \\
\end{array}$ \\
\hline $\begin{array}{l}\text { Program } \\
\text { Development }\end{array}$ & 347 & 51 & 58 & 65 & 57 & 60 \\
\hline $\begin{array}{l}\text { Employee } \\
\text { Involvement }\end{array}$ & 96 & 90 & 90 & 90 & 93 & 95 \\
\hline Tracking & *175 & $\begin{array}{r}34 \\
(35) \\
\end{array}$ & $\begin{array}{c}34 \\
(17) \\
\end{array}$ & $\begin{array}{c}34 \\
(17) \\
\end{array}$ & $\begin{array}{c}37 \\
(17) \\
\end{array}$ & $\begin{array}{c}51 \\
(17) \\
\end{array}$ \\
\hline Reporting & 74 & 135 & 135 & 135 & 138 & 165 \\
\hline $\begin{array}{l}\text { Sitewide Waste } \\
\text { Reduction }\end{array}$ & $\begin{array}{r}378 \\
* 137 \\
\end{array}$ & $\begin{array}{c}412 \\
(134) \\
\end{array}$ & $\begin{array}{r}412 \\
(67) \\
\end{array}$ & $\begin{array}{r}412 \\
(67) \\
\end{array}$ & $\begin{array}{l}415 \\
(67) \\
\end{array}$ & 479 \\
\hline $\begin{array}{l}\text { Technical } \\
\text { Assistance } \\
\end{array}$ & $\begin{array}{r}183 \\
* 400 \\
\end{array}$ & $\begin{array}{l}130 \\
(405) \\
\end{array}$ & $\begin{array}{c}130 \\
(527) \\
\end{array}$ & $\begin{array}{r}135 \\
(548) \\
\end{array}$ & $\begin{array}{c}349 \\
(316) \\
\end{array}$ & $\begin{array}{r}318 \\
(316) \\
\end{array}$ \\
\hline $\begin{array}{l}\text { Information and } \\
\text { Technology } \\
\text { Exchange }\end{array}$ & $* 8$ & $\begin{array}{l}17 \\
(17)\end{array}$ & $\begin{array}{l}20 \\
(34)\end{array}$ & $\begin{array}{l}20 \\
(34)\end{array}$ & 57 & $\begin{array}{l}60 \\
(30)\end{array}$ \\
\hline $\begin{array}{l}\text { Program } \\
\text { Evaluation }\end{array}$ & & 8 & 10 & 15 & 23 & 25 \\
\hline $\begin{array}{l}\text { TOTALS: } \\
\text { Target } \\
\text { Planning/U.S. } \\
\text { Department of } \\
\text { Energy- } \\
\text { Headquarters } \\
\text { Combined }\end{array}$ & $\begin{array}{l}1094 \\
\star 714 \\
1808\end{array}$ & $\begin{array}{l}928 \\
(695) \\
1623\end{array}$ & $\begin{array}{c}944 \\
(715) \\
1659\end{array}$ & $\begin{array}{l}961 \\
(736) \\
1697\end{array}$ & $\begin{array}{c}1261 \\
(475) \\
1736\end{array}$ & $\begin{array}{l}1348 \\
(429) \\
1777\end{array}$ \\
\hline
\end{tabular}


WHC-EP-0496, Rev. 1

Table 2

\section{WESTINGHOUSE HANFORD COMPANY \\ POLLUTION PREVENTION PROGRAM \\ GENERATOR GROUP ELEMENTS*}

\begin{tabular}{|c|c|c|c|c|c|c|}
\hline $\begin{array}{l}\text { KEY GENERATOR } \\
\text { GROUP PROGRAM }\end{array}$ & \multicolumn{6}{|c|}{$\begin{array}{l}\text { FUNDING LEVEL } \\
(\$ K)\end{array}$} \\
\hline FISCAL YEAR & 1994 & 1995 & 1996 & 1997 & 1998 & 1999 \\
\hline $\begin{array}{l}\text { Organization and } \\
\text { Infrastructure }\end{array}$ & 174 & 183 & $\begin{array}{c}199 \\
(26) * * \\
\end{array}$ & $\begin{array}{l}210 \\
(33) \\
\end{array}$ & $\begin{array}{r}221 \\
(30) \\
\end{array}$ & $\begin{array}{r}237 \\
(35) \\
\end{array}$ \\
\hline $\begin{array}{l}\text { Facility Program } \\
\text { Development }\end{array}$ & 162 & 176 & $\begin{array}{r}196 \\
(49) \\
\end{array}$ & $\begin{array}{l}199 \\
(61)\end{array}$ & $\begin{array}{l}205 \\
(61)\end{array}$ & $\begin{array}{l}213 \\
(66)\end{array}$ \\
\hline $\begin{array}{l}\text { Sitewide Program } \\
\text { Participation }\end{array}$ & 337 & 408 & $\begin{array}{r}437 \\
(74) \\
\end{array}$ & $\begin{array}{r}463 \\
(79) \\
\end{array}$ & $\begin{array}{l}480 \\
(78) \\
\end{array}$ & $\begin{array}{r}488 \\
(80)\end{array}$ \\
\hline $\begin{array}{l}\text { Facility } \\
\text { Training }\end{array}$ & 243 & 238 & $\begin{array}{r}224 \\
(69) \\
\end{array}$ & $\begin{array}{l}225 \\
(76) \\
\end{array}$ & $\begin{array}{l}217 \\
(73) \\
\end{array}$ & $\begin{array}{c}223 \\
(75) \\
\end{array}$ \\
\hline $\begin{array}{l}\text { Opportunity } \\
\text { Assessments }\end{array}$ & 343 & 419 & $\begin{array}{r}454 \\
(432) \\
\end{array}$ & $\begin{array}{c}442 \\
(405) \\
\end{array}$ & $\begin{array}{c}442 \\
(360) \\
\end{array}$ & $\begin{array}{r}436 \\
(333) \\
\end{array}$ \\
\hline $\begin{array}{l}\text { Opportunity } \\
\text { Implementation }\end{array}$ & 978 & 719 & $\begin{array}{c}780 \\
(2183) \\
\end{array}$ & $\begin{array}{c}815 \\
(3213) \\
\end{array}$ & $\begin{array}{c}820 \\
(3246)\end{array}$ & $\begin{array}{c}835 \\
(2585)\end{array}$ \\
\hline $\begin{array}{l}\text { Design } \\
\text { Considerations }\end{array}$ & 79 & 80 & $\begin{array}{c}87 \\
(19) \\
\end{array}$ & $\begin{array}{c}88 \\
(30) \\
\end{array}$ & $\begin{array}{r}84 \\
(30) \\
\end{array}$ & $\begin{array}{l}101 \\
(33)\end{array}$ \\
\hline $\begin{array}{l}\text { Program } \\
\text { Evaluation }\end{array}$ & 37 & 37 & $\begin{array}{l}50 \\
(7)\end{array}$ & $\begin{array}{r}56 \\
(9) \\
\end{array}$ & $\begin{array}{r}56 \\
(9) \\
\end{array}$ & $\begin{array}{l}61 \\
\text { (9) }\end{array}$ \\
\hline $\begin{array}{l}\text { TOTALS } \\
\text { Target } \\
\text { (Planning) }\end{array}$ & 2356 & 2241 & $\begin{array}{c}2430 \\
(2859) \\
\end{array}$ & $\begin{array}{r}2501 \\
(3906) \\
\end{array}$ & $\begin{array}{r}2528 \\
(3889) \\
\end{array}$ & $\begin{array}{r}2597 \\
(3216) \\
\end{array}$ \\
\hline
\end{tabular}

* Westinghouse Hanford Company P2 Program generator group funding data was extrapolated for the key program elements.

**(Planning Case). 
WHC-EP-0496, Rev. 1

\section{DISTRIBUTION}

Number of Copies

ONSITE

$4 \quad$ U.S. Department of Energy

Field Office, Richland

E. B. Dagan

A5-15

R. G. Holt

A5-15

S. H. Wisness

A5-15

RL Public Reading Room

Al-65

1. Hanford Environmental Health Foundation

S. Gilchrist

H1-77

T. W. Harrison

$\mathrm{H} 1-77$

4 Bechtel Hanford, Inc.

D. K. Duvon

$\times 5-55$

D. B. Encke

$\times 5-53$

R. J. Landon

H4-80

R. A. Lewis

H4-80

17 ICF Kaiser Hanford Company

R. L. Baker

S2-34

D. L. Barron

S2-12

H. L. Budweg

G7-11

B. J. Dixon

G7-33

W. S. Dunnivant

G3-04

D. R. Herman

S2-12

E. L. Lamm

R. E. Lynne

G4-10

C. E. Marple

G7-33

R. K. McElroy

S2-34

J. H. Mizner

S2-34

A. D. Poor

G7 -33

S. M. Samoray

L6-55

M. L. Sills

L6-55

D. E. Stocker

S2-12

L8-10

P. L. Taylor

G3-04

M. E. Tenvooren

S2-53

6 Pacific Northwest Laboratory

W. J. Bjorklund

P7-68

T. L. Kuusinen

K3-75

R. R. Nielson

P7-79

K. B. Selby

P7-79

H. T. Tilden

P7-79

Hanford Technical Library

P8-55 
WHC-EP-0496, Rev. 1

DISTRIBUTION (cont)

Number of copies

ONSITE

80 Westinghouse Hanford Company

D. Alison R2-86

B. A. Austin B2-30

C. S. Barr T5-54

G. D. Baasch G1-56

T. G. Beam $\$ 6-70$

H. L. Benny $\quad$ L7-09

M. D. Betsch $\quad$ B2-22

P. C. Berlin N3-13

R. K. Biyandi L5-31

D. M. Bogen $S 6-65$

J. F. Brown G2-06

S. E. Campbe11 T4-05

F. J. Carvo N1-41

R. D. Clements $\quad \mathrm{S4-25}$

P. J. Crane T3-28

K. H. Cronin L6-36

E. C. Dahlin G1-20

J. D. Dederick B2-16

J. L. Demarest G2-06

R. G. Dieffenbaker H6-01

D. S. Dutt L6-39

J. A. Eacker R1-51

T. O. Els A2-50

J. A. Engel B2-22

L. J. Estey T5-50

D. J. Farquhar B1-24

D. A. Faulk T5-54

G. W. Faulk T3-28

B. C. Floyd B2-22

D. L. Flyckt R3-45

M. M. Feucht Rl-51

C. J. Geier R2-54

W. O. Greenhalgh L5-31

P. R. Gunter SO-46

R. D. Gustavson R1-51

D. L. Halgren $\quad S 6-70$

M. J. Hall T6-07

J. E. Ham

W. H. Hamilton Jr. N3-10

D. G. Hamrick R1-51

P. L. Hapke T4-05

D. E. Hare \$3-97

J. R. Hilliard S6-19

N. O. Hinojosa $\times 0-35$

J. J. Holmes $\quad$ L5-55 
WHC-EP-0496, Rev. 1

DISTRIBUTION (cont)

\section{Number of copies}

\section{ONSITE}

80 Westinghouse Hanford Company (cont)

M. B. Jaeger

L4-02

C. R. Joseph

B2-22

J. R. Kirkendall

J. M. Kisielnicki

B2-22

G. J. LeBaron

P. E. Lemargie

D. W. Lindsey

C. D. Lucas

D. J. McBride

L6-13

S6-19

B1-24

$\mathrm{H} 4-21$

$\mathrm{XO}-35$

T5-54

K. S. McDowe 17

G2-06

D. S. Merry

B2-22

R. J. Meyer

G1-56

P. C. Miller

N2-04

A. S. Mortensen

T3-28

G. L. Neer

L6-13

D. H. Nichols

B2-22

F. H. Nunamaker

L6-36

R. A. Otte

G5-03

E. A. Raney

B2-22

D. E. Rasmussen

N1-47

R. A. Riggers

L. E. Russell

N1-58

J. A. Seamans

N3-06

T. W. Seifert

N1-36

N. R. Smith

R. M. Suyama

R1-51

G1-67

R. W. Szelmeczka

H5-60

J. B. Toon

$\mathrm{N} 1-73$

M. R. Vasquez

T4-03

M. J. Vitulli

T7-39

$\times 8-29$

H. R. Voge 1

L4-96

E. C. Vogt

T5-50

E. F. Votaw

G2-02

D. J. Watson

XO-41

Central Files

L8-04

OSTI (2)

A2-36 
WHC-EP-0496, Rev. 1

This page intentionally left blank.

Distr-4 